\title{
Differential Publics-Reading (in) the Postcolonial Novel
}

\author{
Elleke Boehmer
}

\begin{abstract}
This essay discusses the activity of reading in three postcolonial novels from three different national contexts (Dangarembga in Zimbabwe, Kapur in India, and Adichie in Nigeria). The essay considers the scenes of focused, respectful, even canonical reading staged in these novels, alongside the more selective or eclectic "reading" and citation taking place at the level of the narration. On the basis of this contrast, it suggests that the postcolonial and transnational publics interpellated by the novels are sometimes different from the audiences or readers dramatized in the texts. It concludes by pointing to the particularly layered-at once deferential and exploratory-reading that is staged within, and by, the postcolonial novel. The essay is shaped by postcritical, cognitive, and hermeneutic approaches to narrative and reading drawn from Rita Felski, James Phelan, Dan Sperber, and Deirdre Wilson.
\end{abstract}

Keywords: postcolonial reading, postcolonial novel, cognitive approaches, Zimbabwe, India, Nigeria, Tsitsi Dangarembga, Manju Kapur, Chimamanda Ngozi Adichie

\section{What the Text Has Read: Cosmopolitan Publics}

Reading brings a host of different imagined audiences into play, noticeably so in historically fraught postcolonial contexts, and hence as noticeably so within the forum of the postcolonial novel. In the novel, these presences are called up both by characters who read and by the reader her- or himself, in the course of reading, as we will see.

In this essay I will consider situations of reading staged within different postcolonial contexts, most notably the novel, and the notions of the public and of cosmopolitan exchange that these situations invoke. I will suggest that the activity of reading carried out within the postcolonial novel harks back to the forum or nexus of the colonial newspaper and intriguingly reorients the idea of the public along transnational axes that extend far beyond the national public sphere. In so doing, I will further suggest, postcolonial reading (within but also of the novel) appeals to and recharges transnational and cosmopolitan values. Moreover, it does so in a way that at the same time also reanimates the wide range of experiences (engagement, attachment, enchantment, identification, shock, etc.) that reading, postcolonial or

Elleke Boehmer is a professor of world literature in English, on the English faculty at the University of Oxford, and director of TORCH. Her most recent monograph, Indian Arrivals 1870-1915, won the ESSE 2016 prize for literature in English. Her novels include Nile Baby (2008) and The Shouting in the Dark (2015, long-listed Sunday Times Barry Ronge Fiction Prize). (Email: elleke.boehmer@ ell.ox.ac.uk.) 
otherwise, involves. ${ }^{1}$ In saying this, I concur with Rita Felski in her refreshingly bold if also inevitably risky conclusion to The Limits of Critique, a conclusion that at the same time announces a new departure for literary engagement (that is, for engagement over critique). Distancing herself incrementally from the hermeneutics of suspicion that she explores throughout as the standard default approach for literary criticism since the 1980s, Felski sets out to give better and more enthusiastic acknowledgment to the full complexity of aesthetic experience that unfolds when we encounter a text as readers, a complexity that this reading, too, will seek to recognize and to explore.

In offering this response to Felski, I situate my suggestions within the postcolonial field by developing the concept of what might be called postcolonial reading, or the postcoloniality of reading. ${ }^{2}$ Reading, I will suggest throughout, insists on an engagement with other consciousnesses and other imaginations to an extent that makes it, within a postcolonial context, a suitably cross-border and poignant activity. Or to adapt from Felski, here in New Literary History, interpretation or reading "is fundamentally a matter of mediation, translation, even transduction; it is what allows texts to move across temporal, spatial, and cultural boundaries, as they are slotted into new and ever changing frames." 3 This activity of slotting into new frames, or of involvement in alternative thought worlds, as I prefer to style it, correlates interestingly with J. M. Coetzee's thoughts on "the sympathetic imagination" in his 2015 meditation The Good Story, skeptical though they may be. ${ }^{4}$ For Coetzee in this written dialogue with the psychoanalyst Arabella Kurtz, the identifications stimulated by the sympathetic imagination allow us to project ourselves into other mental states and "live [other lives] from the inside." The same process is sparked when we read novels and so come into contact with other lives: our sympathetic intuitions are stimulated, even though they may be relied on only to yield fictional truths. In postcolonial contexts, often characterized by fraught forms of division and separation, this engagement of bridging borders and translating difference can work in particularly effective and striking, if also challenging, ways. Indeed, an interesting further research question to develop from this essay would be to ask whether and how these sympathetic crossborder effects manifest more intensely or strikingly in a postcolonial environment.

Two different kinds of reading, I therefore submit, are generally staged within the novel, postcolonial or otherwise. The first is the narrated scene of reading, where a character is shown to be reading-a significant and often contested, even disruptive, activity in the postcolonial context, as will be shown. Second, there is the reading process itself, the work of the sympathetic imagination, which is directed in both implicit and explicit ways by the narrative, and to which, on occasion, metatextual references might be made. This, too, operates with particular resonance in postcolonial contexts. These two different levels of reading can be related to the levels of the

1 Throughout this essay, with reference to the work of Kwame Anthony Appiah, a cosmopolitan reading public refers to one receptive to texts and influences from across cultural boundaries, yet one that, in colonial times, would also have been shaped by colonial educational institutions. See K. Anthony Appiah, Cosmopolitanism: Ethics in a World of Strangers (London: Allen Lane, 2006).

2 Rita Felski, The Limits of Critique (Chicago and London: University of Chicago Press, 2015), 187-93.

3 Rita Felski, "Introduction," New Literary History 45.2 (2014): v-xi, esp. vi.

4 J. M. Coetzee and Arabella Kurtz, The Good Story: Exchanges on Truth, Fiction and Psychotherapy (London: Harvill Secker, 2015), 133-35. 
told and the telling, as designated by James Phelan in his theory of narrative ethics. ${ }^{5}$ For Phelan, the ethics of the told concerns positions taken in the text, charactercharacter relations and so on, and the ethics of the telling has to do with the narrator's relationship to the characters, and to the audience or readership. Setting aside for the purposes of my analysis Phelan's specific concern with ethics, his concept of narrative levels can be usefully adapted in order to think about the different kinds of public to which these different scenes and processes of reading in the postcolonial novel might refer, and about the linguistic forms and mechanisms through which they are invoked.

Throughout, I am also interested in the idea of interpellation, adapted from Louis Althusser, for whom the term refers to the ways in which ideology is "called up" in a society, through the functioning of educational, legal, cultural, and other structures. Especially salient here for how we understand postcolonial reading is that notion of "calling up," that is, how the postcolonial reader is invited by or invoked within a text, either as a character, or through the text, as its reader. For example, we might ask what kinds of readers or addressees, and what kinds of audience or public, these scenes of reading call up, and, following on from this, what kinds of interactive, transnational, or cosmopolitan values these narrative-addressee and narrator-reader relationships support and encourage? ${ }^{6}$ The question also entails exploring the types of formal features, including citation and italicization, that might help to choreograph and direct these relationships. The referencing of a title for example, such as D. H. Lawrence's once-banned Lady Chatterley's Lover in Nervous Conditions, a novel that Nyasha reads, calls up both her rebelliousness and her privilege as a character, a child of the colonial middle class in Zimbabwe (then Rhodesia), as this manifests at the level of the told, as will be seen. However, the Lawrence reference at the same time marks out the narrative at the level of its telling. It points to an African literary work published in the 1980s, but set in the early 1970s, that positions itself athwart and yet at the same time in relation to the tradition of British modernist writing and hence also in relation to a metropolitan, if contested, canon. It refers to itself as a text that asks to be read against the grain, in transverse, noncompliant and yet still in "English" and "literary" ways. This bears some relationship to intertextuality as Julia Kristeva and others described it in the 1980s, but here the weave of allusion, crossreference, and double-voicedness is not only brought to the text by the writer, or the tradition, but specifically by the reader. My emphasis, therefore, is on those aspects that the reader picks up of the influences and contexts that shape the writing. I consider in particular how the text's own intertexts-in shorthand, "what it has read"-appeal to the reader and draw him or her in.

Two of the novels selected, Tsitsi Dangarembga's Nervous Conditions (1988) and Manju Kapur's Difficult Daughters (1998), though very different in terms of the

5 James Phelan, Experiencing Fiction: Judgements, Progressions and the Rhetorical Theory of Narrative (Columbus: Ohio University Press, 2007), esp.3-4, 11. The second level, of the telling, can include the extratextual reader, who enters the story through identification with the narrator.

6 Louis Althusser, "Ideology and Ideological State Apparatuses: Notes towards an Investigation," Lenin and Philosophy, and Other Essays, trans. Ben Brewster (London: Monthly Review Press, 1971). See also: Fredric Jameson, The Political Unconscious: Narrative as a Socially Symbolic Act (London: Methuen, 1981), 47-49; and https://www.marxists.org/reference/archive/althusser/1970/ideology.htm, accessed July 27, 2016. 
postcolonial contexts from which they emerge, are strongly comparable for the purposes of this analysis as tales of individual growth. The third, Chimamanda Adichie's Half of a Yellow Sun (2006), her historical novel concerning the 1967-1970 Nigerian-Biafran war, provides an interesting counterpart, in that individual development is not as much to the fore. Yet the main characters' reading, certainly the in part self-educated houseboy Ugwu's, incrementally creates heuristic frames through which the upheavals and reversals of the war can be understood. ${ }^{7}$ Ugwu's, too, is on some levels a tale of individual growth. The novels by Dangarembga and Kapur both deal with middle-class women's Bildung, that is, their growth or growing up, adjusted to their different (post)colonial contexts, and both cast reading as an important part of such development. Based on her observations of her uncle and brother, reading for the young Tambudzai in Nervous Conditions is a way to progress and advance now educationally and now socially, while Virmati the central character in Difficult Daughters, sees reading, as does Tambu, as a mode of self-education and so as the only viable alternative to marriage. ${ }^{8}$ In these ways the novels directly invoke reading as Bildung within the narrative itself-at the level of the told, or of characterizationwhile they at the same time both implicitly and explicitly cast reading as a transformational activity at the level of the narration (that is, of narrative structure, voice, and address, including real-world address). For Half of a Yellow Sun, too, reading is transformational in how it provides vehicles for both the reader and Ugwu not only to understand and come to terms with the impacts of the war, but also to enter sympathetically into the lives and the pain of others.

Reading understood in this way, as involving translocal, transnational, and other cross-border modes of identification, including with other publics different from one's own, can also be seen to activate cosmopolitan sympathies. Reading, we identify with audiences elsewhere; we enter into and build an understanding of other worlds. All three of the novels in question call up reading publics that reach beyond the communities represented within the work, in a manner that bears interesting comparison with the lateral and cross-border relations also established in situations of subaltern or native colonial reading. To demonstrate the subversive and transformational effects of reading in both dimensions, colonial and postcolonial, I will in a later section turn back to a situation of colonial reading to outline those of its lateral, cross-cultural, and cross-continental relations that throw up "postcolonial" as well as cosmopolitan continuities and parallels. I will then consider how these continuities are reiterated yet also reshaped and adapted in the reading situations evoked in Dangarembga and Kapur, and in Adichie.

The scene in which the middle-class woman is pictured reading, a seemingly ubiquitous tableau for the Bildungsroman, is well developed in Nervous Conditions as it is in Difficult Daughters, yet this universal scene at the same time bears recognizable postcolonial and national features. In a longer analysis, examples from the two novels might be read alongside related case studies from other keynote postcolonial

7 Tsitsi Dangarembga, Nervous Conditions (London: The Women's Press, 1988); Manju Kapur, Difficult Daughters (London: Faber, 1998); Chimamanda Ngozi Adichie, Half of a Yellow Sun (London: Fourth Estate, 2006).

8 Dangarembga, Nervous Conditions, 5; Kapur, Difficult Daughters, 38. Page references will henceforth be cited in the text, along with the abbreviations $N C, D D$, and HYS. 
Bildungsromane or, more broadly, novels of formation, including, again with due respect to national and regional differences, Merle Hodge's Crick, Crack Monkey, Jamaica Kincaid's Lucy, Andrea Levy's Small Island, Anita Desai's Clear Light of Day, or Chimamanda Adichie's own novel of female self-formation, Purple Hibiscus (2004). ${ }^{9}$ Indeed, it would be an interesting investigation for this longer study whether the dual invocation of the postcolonial reader that is explored in this essay, as it is played out at the levels of the told and the telling, is a scenario integral to postcolonial fiction, as it positions itself always through a double optic in relation to at once mainstream European and (emergent and established) national traditions. ${ }^{10}$

To pose this as a question that addresses all of the aforementioned novels, yet also extends far beyond the confines of this essay, might this dual invocation in fact comprise a foundational scenario within the postcolonial text? Or, in different terms, might this double address allow the text to interpellate different and even split readerships, that is, readerships that are nationally based on the one hand, and transnational or global on the other (though there may be an overlap between them, as can occur with readers in diaspora). Half of a Yellow Sun, for example, appeals to metropolitan Anglophone readers of Joyce Cary and (arguably) also John Le Carré, as well as regional West African and national Nigerian readers of, say, Chinua Achebe or Ferdinand Oyono. ${ }^{11}$ As this mention of Anglophone readers alongside a Francophone writer, Oyono, might suggest, this double address is importantly of course facilitated both by the narrative medium, the globalized English language, and what might be called its standardized narrative idiom, comprising widely recognizable literary devices including character and voice, as well as Bildung structures, accessible to different audiences yet variously interpreted by them. ${ }^{12}$ Unless, however, the novel has been translated (as was Cameroonian Oyono's Houseboy from Une vie de boy), the language medium can also exclude sectors of its wished-for national readership, thus compromising to some degree its attempt to address the whole nation.

As I will show, the often transnational forms of address that the texts deploy draw interesting attention to the contiguity of postcolonial middle-class reading publics who imagine themselves when reading as located both within their particular postcolonial and often national context, and yet at the same time as proximate to middle-class readerships elsewhere. A very similar transnational relatedness can be detected in scenes of colonial reading. So in Dangarembga's late-colonial Rhodesian world, for

9 Merle Hodge, Crick Crack, Monkey (London: Heinemann, 1981 [1970]); Jamaica Kincaid, Lucy (London: Cape, 1991); Andrea Levy, Small Island (London: Review, 2004); Anita Desai, Clear Light of Day (London: Heinemann, 1980); Chimamanda Adichie, Purple Hibiscus (London: Fourth Estate, 2004). 10 Joseph Slaughter, Human Rights, Inc.: The World Novel, Narrative Form, and International Law (New York: Fordham University Press, 2007), 228-46, makes a compelling, rightly celebrated case for Dangarembga's repurposing of the forms and tropes of the Bildungsroman in order to address the violent and truncated history of colonialism. My own substitution of the phrase "novels of formation" for Bildungsromane previously takes account of this adaptation and repurposing. Slaughter is not, however, specifically concerned with reading situations in Dangarembga.

11 Oyono is notable in this essay for having, like Adichie, produced a novel centered in the experiences of a houseboy.

12 Though her focus is more on language than on literary idiom, these devices bear some characteristics of "born translated" writing, as described by Rebecca Walkowitz, Born Translated: The Contemporary Novel in the Age of World Literature (New York: Columbia University Press, 2015). 
example, reading can be a subversive activity, whether it involves resisting patriarchy or whether colonialism. At another level, however, the reading pathways that the novel calls up, the narratives to which it refers, or, again, what the text has read and how it interpellates the reader, subscribes to a settled culture of "good," if generic, canonical English reading, one informed by English values and a sense of English literary tradition and identity. ${ }^{13}$ This same "Englishness," fostered and sustained throughout by her own and her father's colonial education, is the thing that Nyasha at once consumes and purges in the closing scenes of the novel, cursing it for having turned her father into a colonial stooge, a "good munt" (NC 202).

\section{Perspectives on (Postcolonial) Reading}

Like other contributions to this special issue, this essay is centrally interested in how still emergent new concepts of reading, of the process of receiving, interpreting, and interacting with texts, play out in postcolonial and related audiences and publics. Its approach is at once cognitive, and linguistic or communication based. It is not unaware of the symptomatic, distant, surface, algorithmic, and other kinds of reading practice that have, variously, exerted a normative force in the academy since the 1980s, and in many cases continue to do so. Yet it also recognizes that questions of reading-of what counts as reading, of the cognitive though also material practices involved in reading-have gained new prominence on literary critical agendas, and it seeks to respond to this growing understanding of reading as a constantly unfolding inferential process, as Dan Sperber and Deirdre Wilson have influentially described it. ${ }^{14}$ Relevance theory, as Sperber and Wilson call their linguistics-based approach, and the literary critical frameworks that might be derived from it, deserves more careful exposition than I am able to give here. The aspect of their theory that is particularly suited to my purposes, however, is the idea that comprehension, including reading, far from involving a now-well-understood decoding of linguistic signals, as semiology might have it, or the interpretation of clues to the disguised operations of history, as in Fredric Jameson's Marxist readings, rather puts any number of conceptual representations in play and that these are then expanded or delimited as the communication (here the reading) unfolds. In other words, any reading sets off a cascading of inferences, which the reader processes at different simultaneously unfolding cognitive (semantic, sensory, kinesthetic) levels. ${ }^{15}$ Because this essay's focus is directed primarily at the postcolonial literary work, however, it is especially concerned not just with the complex dynamics of such processing, but also with how these dynamics play out within this specific literary domain. In other words, how do the environs and publics of the postcolonial text (within and without the novel) inform comprehension?

13 Ankhi Mukherjee, What Is a Classic?: Postcolonial Rewriting and the Invention of the Canon (Stanford: Stanford University Press, 2014), 139-40, interestingly refers to the novel's disregard for the "singularity" of the classic English texts it cites.

14 Dan Sperber and Deirdre Wilson, Relevance: Communication and Cognition, 2e (Oxford: Blackwell, $2004[1986])$.

15 See Terence Cave, Thinking with Literature: Towards a Cognitive Criticism (Oxford: Oxford University Press, 2016), for a suggestive and persuasive adaptation of relevance theory specifically for literary reading. 
Reading, crucially, does not involve merely the application or imposition of a meaning or framework upon a piece of writing. Rather, reading is taken to involve imaginative and cognitive interaction with that writing, or the repeated application of inferential procedures to it. Throughout this process, tentative hypotheses about content, context, and communicative effects are mutually adjusted in relation with one another. Reading, therefore, is not merely symptomatic, as it was for many critics in the 1980s and 1990s, who charged a text with breaks, hiatuses, refusals, and interdictions as signs of deep-seated contradictions of which the surface text itself remained ignorant. According to this approach, reading also turns from the strong reliance on surface versus depth distinctions that marked out this theory, and from the belief that more fundamental truer interpretive codes were located at deeper levels. Reading, therefore, is also more than "a first orientation toward an array of data," as the art historian T. J. Clark, too, would have it, given that this definition commits the reader to an observer position outside the text, as, too, does the idea of excavating form for content. ${ }^{16}$

Instead, as also for Sperber and Wilson, reading is here taken to commit the reader to an engagement with the "spreading" semantic activation patterns that any textual sequence sets in motion, yet also channels and constrains. ${ }^{17}$ Reading, therefore, is less about assessing representations than it is about attending, intensively, and in an internalized way, to the semantic processes through which meaning unfurls. Or, as Mary Crane and Christopher Nealon from their different cognitive and materialist perspectives recognize, hermeneutics is not what critics do to the poem because interpretation is happening in the poem. ${ }^{18}$ The poem (or other text or literary work) itself is where the meanings circulate. Therefore, when reading, we do not need to add theory to our experience of the text, but rather "register what the text itself is saying." Our task, in effect, is to follow its cognitive processes, which here includes attempting to understand and interpret how its meanings may play out in postcolonial contexts, and in relation to postcolonial and also cosmopolitan publics.

It is interesting to observe how sharply distinct this cognitive approach to reading is from theories of language as comprising complex code, and hence of literature as a highly sophisticated yet also contradictory version of that code that requires unpicking, extraction, and interpretation. If, as this approach suggests, reading involves a constant outpouring of inferences, followed by a filtering out of the more relevant of these, then what matters is how the text communicates, and, more particularly, how the reader as interpreter is engaged with the text. By reader I again refer both to the reader within the text, the represented reader-here Tambu, Virmati, or Ugwu-and the reader without-you, me, but also the author, the first reader of their text. (Indeed, in particular where they adopt a surrogate within the text, as

16 T. J. Clark, "Poussin's Sacrament of Marriage," New Literary History 45.2 (Spring 2014): 221-52, esp. 224. See also Zhang Longxi, "The Pale Cast of Thought: On the Dilemma of Thinking and Action," New Literary History 45.2 (Spring 2014): 282-97.

17 See again the readings developed in Terence Cave, Thinking with Literature.

18 See the special issue of Representations 108.1 (Fall 2009) on "The way we read now," in particular, editors Stephen Best and Sharon Marcus's "Surface Reading: An Introduction," 1-21; Christopher Nealon, "Reading on the Left," 22-50; Mary Crane, "Surface, Depth and the Spatial Imaginary: A Cognitive Reading of The Political Unconscious," 76-97. 
Dangarembga clearly does with Nyasha, the postcolonial author is an especially active intertextual agent, constantly rereading, "unreading," and intentionally misreading their source and precursor texts. ${ }^{19}$ ) The reader without builds a certain involvement with the different layered structures making up the text, including its characterization (and including its characters who read). This is reading for the told. But at the same time the reader without is positioned as part of a network of possibilities that the process of the telling, the fictional process, both consciously and unconsciously triggers.

It is at this second level-the level of the telling - that the text potentially draws in other publics, and hence double-voiced references from beyond its immediate cultural purview. And it is at this level that the reader then responds to and expands on the at once inter- or transcultural and cosmopolitan links that the text and its author buildand, we should add, cannot but help build. For the postcolonial reader, therefore, the important aspect of these links is how they may clarify, highlight, support, or undermine the cross-border, postcolonial, or decolonial situation in which both the reader and the text might be situated. To illustrate, in In the House of the Interpreter, his memoir of his school years at Alliance School in Kenya during the Mau Mau uprising, the veteran African writer Ngugi wa Thiong'o offers a candid and illuminating delineation of these two levels and how together they describe the contradictions of the late and then postcolonial African condition. ${ }^{20}$

Indicatively, In the House of the Interpreter is itself a companion or diptych text to Dreams in a Time of War: A Childhood Memoir, which narrates Ngugi's early experiences of the uprising's dislocations and hence is at least in its subject matter more obviously anticolonial. At one level in the later narrative-at the level of the told-the memoir's protagonist, the older author Ngugi, outlines the interests and experiences of his younger, once-Christian colonial self, a persona recognizably as obedient and grateful as Tambudzai or her uncle Babamukuru. His colonial complicity comes through clearly in the account he gives with remarkably minimal irony of his school reading at Alliance, guided by the eccentric Cambridge-educated head teacher, Edward Carey Francis. Ngugi lists the presence of the Bible and hymnbooks, performances of Shakespeare plays such as Julius Caesar or Macbeth, and, perhaps most significantly, immersive experiences of Carey Francis himself reading aloud and preaching from, respectively, Jerome K. Jerome's Three Men in a Boat and Bunyan's Pilgrim's Progress. Yet, at the level of the telling, these same readings from his colonial high school days, in particular Pilgrim's Progress, as the titular reference to Bunyan's "House of the Interpreter" suggests, signify in more arch, knowing, and intertextual ways. ${ }^{21}$ These reverse and rework (perhaps also unread) the earlier obedient readings, though, interestingly, without discrediting their pleasure. Playing this level of the telling contrapuntally against the first, the level of the told, Ngugi is able to point his readers to the decolonial potency of reading, through which subjection to the master

19 Many thanks to Ankhi Mukherjee, editor of this special issue of the Cambridge Journal of Postcolonial Literary Inquiry, for pointing me to this observation.

20 Ngugi wa Thiong'o, In the House of the Interpreter: A Memoir (New York: Pantheon Books, 2012), esp. 42-44, 46-47, 50-52. See also Ngugi, Dreams in a Time of War: A Childhood Memoir (New York: Pantheon, 2010).

21 Ngugi wa Thiong'o, In the House of the Interpreter, 42-52. 
"Interpretation" that is a colonial education, is unraveled by being intercut and juxtaposed with countervailing texts and interpretations, not excluding Shakespeare. Interestingly, in Ngugi's specific case, the different possible reading pathways that his intertextual references plot through the memoir, go some way toward accounting for his formation as an ethnic nationalist who at the same time appeals to cosmopolitan readerships. Across his career his ideological orientation might also be said to have overridden or even "overwritten" his readings in the canon. ${ }^{22}$

\section{Transnational Reading Publics}

So far, this essay has focused mainly on reading as it manifests at different cognitive levels within texts and on how these levels interpellate readers (especially postcolonial readers). It is worth being reminded, however, that texts are consumed and interpreted within particular contexts (here especially national and postcolonial). I'd like to do this by turning to a specific example of cross-cultural identification that I have drawn from my own research into colonial newspaper reading in India. ${ }^{23}$

Studies of both novel and newspaper reading in colonial contexts show that colonial readers adept in several languages, for example in British India or in colonial Nigeria, often conceived of themselves as (differentially) conversant with local, national, and international publics, and so as virtual intercultural travelers, without their having physically to leave their home cities or communities, or formally become part of a transnational audience. ${ }^{24}$ Colonial journalism, too, tended to imagine and invoke readerships at once at home and abroad, and so appealed to and bolstered colonial readers' sense of their world citizenship, as Isabel Hofmeyr has shown. ${ }^{25}$ It is a significant continuity of colonial into postcolonial reading practice that, as we will see, different levels of address and hence of reading activity can also be distinguished within the postcolonial novel and in its publics.

Whereas colonial reading is generally seen as ideological, controlled, and regulated-we might think of the recommendations for a colonial canon offered in Thomas Babington Macaulay's "Minute on Indian Education" (1835) - it is often assumed that postcolonial reading is intrinsically subversive, resistant, and recalcitrant. Any comparative analysis of postcolonial as against colonial reading is bound to explore, however, the extent to which this is in fact so: whether colonial reading was not more uneven, layered, fissiparous, and multidirectional than it is generally given credit for being, and also, relatedly yet conversely, whether postcolonial reading is not more respectful, conformist, and obedient than its prima facie anticolonial

22 I am grateful to the Cambridge Journal of Postcolonial Literary Inquiry editor Ato Quayson for pointing this out to me.

23 See Elleke Boehmer, Indian Arrivals 1870-1915: Networks of British Empire (Oxford: Oxford University Press, 2015), 92-108.

24 As well as Indian Arrivals, see Antoinette Burton and Isabel Hofmeyr, eds., Creating an Imperial Commons: Books that Shaped the Modern British Empire (Durham NC: Duke University Press, 2014); Priya Joshi, In Another Country: Colonialism, Culture and the British Novel in India (New York: Columbia, 2002); Stephanie Newell, Literary Culture in Colonial Ghana: "How to Play the Game of Life" (Manchester, Manchester University Press, 2002).

25 Isabel Hofmeyr, Gandhi's Printing Press: Experiments in Slow Reading (Cambridge MA: Harvard University Press, 2013). 
connotations might suggest. The two levels of reading outlined previously allow us to tease out these differences, showing how scenes of reading in the postcolonial novel, especially where they interpellate transnational publics and cosmopolitan values, often extend and reinforce rather than undo these cross-border, contiguous, yet often also post-imperial and global relations. Conversely, the implied reader of a piece of colonial journalism was in many cases invoked as more imaginatively adventurous and hence as radically proximate (even when geographically distant) than the standard account of subaltern intellectual passivity that has since developed might allow.

If, as Benedict Anderson contends, the world was imagined, re-imagined, and consumed on a daily basis in part by way of the nineteenth-century newspaper's format and its mass propagation, these were processes that happened in Lagos, Lahore, and Lilongwe as well as in London or Leeds. ${ }^{26}$ The vocabularies through which city spaces were described (multilingual advertisements side by side with references to English language theater and musicals), thus became formalized as synecdoches of an urban life across (in this case) the Anglophone world, forming part of what Partha Mitter terms the "virtual cosmopolitan" know-how of colonial writers and readers. As Mitter writes, colonial cities formed significant hybrid cosmopolises, transregional and intercultural environments distinguished by their cosmopolitan character and heterogeneous social relations. ${ }^{27}$ And colonial readers were drawn or interpellated into a global virtual community precisely by dealing in such heterogeneous vocabularies; by enlisting themselves, as readers, to such virtual intercultural groupings.

As this implies, colonial audiences reading their local or national newspaper within these spaces, or consuming colonial magazines, advice manuals, textbooks, guidebooks, and adventure fictions, made up a self-consciously international public involved in a range of two-way or even multidirectional cultural relationships. ${ }^{28}$ Interpellated at one and the same time into local, national, and global networks, these colonial writers and readers engaged with situations, communities, and belief systems very different from their own, yet not in a secondary or belated way, but on relatively equal terms. The situation represents an interesting expansion and complication of Anderson's own monadic model of newspaper reading as nation making. Indeed, I would want to propose that the scene of reading conjured within and by colonial journalism, and, perhaps more intensively so, the postcolonial novel, dynamically extends if not ruptures the confines of Anderson's reading capital. As does Ugwu when he draws his lengthy history of Biafra out of the relatively small worm-hole that his sentimental knowledge of Achebe and other African writers has provided

26 See Benedict Anderson, Imagined Communities, rev. ed. (London: Verso, 1991), esp. 35-46; Benedict Anderson, The Spectre of Comparisons (London: Verso, 1998).

27 Partha Mitter, The Triumph of Modernism (London: Reaktion, 2009), esp. 10-11, 229. Indian cities, Mitter writes, were dynamic sites where Western capital and the forces of global modernity most forcefully impacted on the subcontinent, and where, in consequence, fruitful interactions between near and far, global and local, the Western avant-garde and home-grown anti-colonialists, took place. See also Felix Driver and David Gilbert, eds., Imperial Cities: Landscape, Display and Identity (Manchester: Manchester University Press, 1999).

28 On the transnational circulation of texts in the British Empire, see Burton and Hofmeyr, eds., Creating an Imperial Commons; Priya Joshi, In Another Country: Colonialism, Culture and the British Novel in India (New York: Columbia, 2002), discusses Victorian readerships in India in illuminating detail. 
(including of texts such as Chike and the River and Things Fall Apart), as we will again see, the postcolonial novel retraces but also exceeds the heterogeneous proximate worlds called up by the colonial text or newspaper (HYS 292, 433). In this way it forges transnational and cosmopolitan links in ways that are potentially world making and calls up new transcontinental and intercultural formations.

\section{Postcolonial Reading Situations}

The scene in Dangarembga's Nervous Conditions in which Nyasha reads Lawrence's Lady Chatterley's Lover, and then has her book confiscated by her father, has, nearly thirty years after the novel's first publication, not lost its force as a resistant postcolonial act. As we know, that force is thwarted, however, by conservative (and seemingly colonial) authority embodied in the form of her father, who when he encounters her reading the novel, roughly dispossesses her of it $(N C 75,81,83)$. By taking a risk and choosing to read Lawrence's once-banned book, Nyasha is kicking against her own inescapable yet cloying cultural hybridity (NC 78), and her and her parents' Anglicization (74). This is symbolized also in the bed clothes they all wear, their daily routines, and her mother's studied social graces and rose-patterned tea set. At the level of the told, all of these objects and practices are called into question by Nyasha's choice of book and passionate identification with it; at the level of the telling, the reiteration of Lawrence's novel title marks this novel out as similarly recalcitrant and unruly.

Yet elsewhere in the novel, and certainly where it comes to Nyasha's more compliant and grateful cousin Tambudzai, reading is a far more conformist than it is a rebellious activity. Though Tambu's ambition to acquire an education despite being a girl involves her making some socially subversive decisions, her desire not only to read but also to read widely, is symbolically circumscribed by the Anglophone canon of children and young women's reading. Putting together a book list that extends as it were across the whole narrative, Tambu reads or is said to read the colonial newspaper alongside Enid Blyton, the Brontës, and Louisa M. Alcott (NC 33, 93, 117), her ostensibly free choice hemmed in by these familiar English and metropolitan points of reference. Indicatively, none of these cited titles or author names is attached to an actual scene of reading within the novel.

The structural level of the narration, Phelan's "telling" level comprising "what the text has read," is situated within the same circumscribed colonial terrain. From Tambu's first line, "I was not sorry when my brother died" (NC 1), the novel can be seen to reference an English literary field of orphan, upstart, and surrogate tales, most notably Charles Dickens's form-giving Great Expectations, as well as of course pointing to its own situation of intense sibling rivalry. As such, Nervous Conditions calls up a literary public educated in this field and participating in its values. Moreover, these values are not so much colonial or even postcolonial as international, encouraging identification across borders, cosmopolitan exchange. They also diverge from the sense of national pride and national belonging that Nyasha, reading Lawrence, inchoately attempts to express. Tambu's late-colonial cultural world lies at a generational remove from Adichie's Half of a Yellow Sun or indeed Purple Hibiscus, in which, by contrast, the experience of reading Achebe is woven into both the 
characters' imaginative worlds and the texture of the narrative. Within the obedient "English" world of Babumukuru's Rhodesian mission school, a bookshelf containing work by Chinua Achebe would be inconceivable. Similarly, for the school-boy Ngugi in In the House of the Interpreter, seeing Peter Abraham's Tell Freedom in his teacher and scoutmaster Allan Ogot's hand delivers "a silence more soaring" than any sermon, yet at this point the vision it offers remains a glimpse only. ${ }^{29}$ In Nervous Conditions, within the binary described by the purging but weakened Nyasha, on the one hand, and the ambitious and determined yet compromised Tambu on the other, the reader has difficulty in discerning what freedom might entail for the two cousins. Tambu aspires to the same condition of alienated colonial modernity that has so deeply damaged Nyasha. A single subversive glimpse of an alternative is given, again at the level of the telling in the novel's title and epigraph, with its reference to the revolutionary work of Frantz Fanon, both his Black Skin, White Masks and The Wretched of the Earth: in Sartre's words in the preface to the latter, 'the condition of native is a nervous condition." 30

Not as well-known as Nervous Conditions, Kapur's Difficult Daughters is also a characteristic postcolonial family romance, one whose fraught genealogy outlines the coming-into-being of not one but two nations, India and Pakistan. ${ }^{31}$ Within this sometimes ruptured national and familial lineage, the protagonist Virmati is both a recalcitrant daughter and a reluctant and self-conflicted mother. Her protracted and often painful relationship with her married English teacher, Harish, called the Professor, runs as a connecting thread through the generational story. Importantly for our purposes, the interest that first draws and then keeps them together is reading, despite the multiple historical forces and tensions that would separate them, embodied not least in the form of their families and their often countervailing values, hers, individualist but also nationalist, his, cosmopolitan. Again and again, most prominently through the years of their protracted courtship, the reader encounters the two lovers reading or aspiring to read. So the Professor teaches Virmati about Shakespeare and English poetry, and she admires his literary inspiration and his devotion to his books, his Keats, and his Alfred Austin. Yet, interestingly, as in Tambu's reading world, these books and authors are referred to as titles and names, but are not drawn into lived scenes of reading within the novel.

At the same time, the two characters' investments in reading are noticeably divergent and non-contiguous. At the level of the told tale, reading takes them on different trajectories of involvement, even though at the level of the telling, the repeated references to their colonial-era reading often arrests or even turns the narrative sequence back on itself, retarding their movement into an unknown nationalist future. Whereas the Professor reads for pleasure, and returns to India from education in England with a trunk full of English books, "bringing as much of England

29 Ngugi wa Thiong'o, In the House of the Interpreter, 27.

30 Frantz Fanon, Black Skin, White Masks, trans. Charles Lam Markmann (London: Pluto, 1986); Frantz Fanon, The Wretched of the Earth, trans. Constance Farrington (Harmondsworth: Penguin, 1965); Mukherjee, What Is a Classic?, 138, 231.

31 See Elleke Boehmer, Stories of Women: Gender and Narrative in the Postcolonial Nation (Manchester: Manchester University Press, 2005), 211-19, for a differently inflected reading of Difficult Daughters as a self-consciously gendered narrative of postcolonial nation building. 
as he could" ( $D D$ 33), not unlike Babamukuru, his beloved reads to improve herself and to seek a vocation rather than take her mother's route of marriage and childbirth. She, however, unlike Tambu, has no particular sense of acquiring thereby an English patina or English culture. And whereas he reads in a purposeless way, expressive of his self-conscious romantic quest for the beautiful, she reads functionally in order to educate herself, so that she may be useful as a teacher outside of marriage. At the level of the telling, therefore, the omniscient narrator (who is, we understand, Virmati's daughter Ida, two letters short of India) works subversively, pointing out through nuance and inflection the extent to which each yearns for their own ideal image or literary companion through their relationship, rather than rejoicing in each other's differences or finding in each other a sympathetic counterpart or alter ego. For both characters, reading, now respectfully colonial, now pragmatically postcolonial, is used at once to stimulate this quest and to shore up this ideal.

The contrast between the characters is clearly etched in two important scenes, both of which involve reading, and which thus become pressure points of maximum intimacy and yet maximum alienation in the narrative. Again, reading at one level draws the protagonists together while on another level it forces them onto divergent tracks. The first scene unfolds the lover's extensive epistolary correspondence, through which they conduct much of their courtship (DD 81-101). The second, the more explicitly post- or even anticolonial, is centered on the couple reading the epitaphs on a pair of colonial graves on a hillside in the princely state of Nahan, where Virmati has secured a teaching job for herself while waiting with dwindling hope on her lover's decision to take her as his second wife. In the correspondence, while the English Professor repeatedly presses his suit and is heatedly focused on his lover's person and interests, Virmati is concentrated in the main on her educational ambitions and vocation as a teacher in the making. He in fact chides her for not taking him into account or even addressing him properly as part of their correspondence. In this sense, instead of her lover, her idealized educated self is the addressee of her correspondence. So she relates to his beloved English literature, Shakespearean tragedy or Wordsworth, for example, in a stubbornly self-centered way, only in so far as these reference points allow her to articulate her own dilemmas and uncertainties (DD 173). Her reading outlines her difference from him, as well as her indifference about upholding or denying cultural authority, whether national or metropolitan.

As for the colonial epitaphs, the lovers encounter these in the period after Virmati's flight from city, driven by the shame she feels at her affair with the Professor. As might be expected, they relate to the cited epitaphs in markedly different ways ( $D D$ 175-77). The Professor once again reads the words according to his romantic interests, with reference to Wordsworth. Virmati, in contrast, is irritated at the devotion expressed by the colonial officer's wife named on the headstone, a woman who seemingly lived on in solitude for thirty years after her husband's death, devoted to his memory. The Professor in his reading and interpretation of the epitaphs appears to invoke first and foremost a virtual reading public abroad, whereas Virmati in her reading subscribes to a public of one, herself. Only implicitly does she gesture to a wider national community of other women readers, including her fellow students, who, like her, turn to literary reading not for inspiration or escape, but because it allows them to describe themselves and their day-to-day predicaments in ways that 
allow them to cope and to survive (as of course does Nyasha through reading Lawrence).

Chimamanda Adichie's Half of a Yellow Sun recounts the history of the NigerianBiafran war from three points of view, the young academic Olanna's, the Englishman Richard's, and Ugwu's, though our focus here is on the self-motivated reader, Ugwu. Literary and historical readings shape the narrative throughout, most noticeably perhaps at the level of telling, which oscillates between the early and the late 1960s, Nigeria at the time of independence, and the same country in a state of civil war. Adichie is on record for saying that her novel's interpretation of a war she only heard about second hand is itself the product of wide reading, and its cultural memory is indeed imbued with other stories, ranging from memoirs and autobiographical fiction, such as Chinua Achebe's Girls at War or Wole Soyinka's The Man Died to formal histories and biography, including those by Herbert Ekwe-Ekwe and Ntieyong Akpan (HYS appendix 2-14). The narrative also refers metatextually to its own process of history making: it is interspersed by extracts from an unfolding history of the war, The World Was Silent When We Died, that we at first are led to assume is the anthropologist writer Richard's (HYS 82, 115, 155, 204, 237, 258, 374). That is to say, the extracts are mainly appended to his sections of the narrative, and his job during the war is to write for the Propaganda Directorate (HYS 305, 374). Through these multiple intertexts, the novel at once addresses itself to a national readership, but also turns outward to a global audience, the ignorant and unconcerned world referenced in the history's title.

The told level of the novel, too, is water-marked throughout by a distinct teleology of reading. As with Tambu or Virmati, Ugwu's story is one of self-development through books, as well as through the experience of living in close proximity to teachers. $^{32}$ Arriving in his master Odenigbo's household with a Standard Two (or Grade 2) education, Ugwu is sent to school and takes to reading. Later, during the war, he is involved in setting up a school, together with Olanna, where he himself teaches reading, from both Achebe and "simplified" Austen. The novel is punctuated across its length by indicative moments (and titles) in which Ugwu is pictured getting to "know book" in the manner of his master, reaching out and consuming when he can everything from the novels and poems he finds on Odenigbo's overflowing shelves, through the Couples' Handbook, to radical newspapers including the Socialist Review and Renaissance (HYS 3, 13, 126, 84, 100, 126, 175, 294). As this suggests, the trajectory of Ugwu's reading choices is conventionally postcolonial, branching out from Browning's "The Pied Piper of Hamlyn" and taking in The Pickwick Papers, The Mayor of Casterbridge, and Drum magazine. The most striking postcolonial citation, however, is reserved for the final two lines of the novel (HYS 433). Here, in a twist properly worthy of Achebe, to whose Things Fall Apart, and specifically its denouement, the reference is made, it turns out that Ugwu has been not only the main reader of the narrative (at the level of the told), but also the writer of the cited history (within the level of the telling). Half of a Yellow Sun thus presents a remarkable example of a novel in which the two narrative levels coincide in terms of their literary reference

32 On Ugwu's sentimental education, see John Marx, Geopolitics and the Anglophone Novel, 1890-2011 (Cambridge: Cambridge University Press, 2012), 70-75. 
points, or "what the text has read," and through their forms of interpellation also, that is, to the nation, Nigeria.

As these three commentaries accumulatively suggest, reading in and of the postcolonial novel involves the differential assertion and retraction of colonial and postcolonial values at both narrative levels and the simultaneous, sometimes contradictory, interpellation of both global and national publics. Indeed, it could be said that the postcoloniality of reading is encapsulated precisely in this quality of contradictoriness, in the tacking between apparently countervailing regimes of knowledge and relationship.

In all three novels, Nervous Conditions, Difficult Daughters, and Half of a Yellow Sun, not only the always prominent reader-characters but also, and perhaps more obviously, the narrators make appeal to a shared literary repertoire that transcends national boundaries and collapses transnational distance, though without then affirming a global or international vision. Even if the scene of reading reaches out beyond national borders, reading itself remains an important form of selfconsolidation and identity-making. Though this may appear at first sight to be a flat and unremarkable observation to make by way of a conclusion, it is offered in a spirit of experimentation and constructive open-endedness. The conjunction of cognitive theory with postcolonial reading remains in its infancy as a critical approach, therefore, its findings as regard the makeup of a text's postcolonial publics must remain at this stage provisional.

At the same time, the reading experiences that these novels evoke positively confirm and enhance the cross-boundary nature of all reading, which is then further heightened in a postcolonial context in relation to situated postcolonial readers. The audience to which the narratives appeal lies always across linguistic, cultural, or national cultural borders. As this implies, the dichotomy of colonial as against postcolonial reading that our twenty-first-century critical perspectives may wish to underwrite needs to be more carefully interrogated, certainly when it comes to the layered, deferential, yet exploratory reading that is staged within, and by, the postcolonial novel. The publics envisaged by such reading often trump difference with sameness and override apparent resistance within the told story with compliance and contiguity at the level of the telling. 